\title{
ANALISIS POTENSI PREBIOTIK GROWOL: KAJIAN BERDASARKAN PERUBAHAN KARBOHIDRAT PANGAN
}

\section{Analysis of Prebiotic Potency of Growol: A Study Based on Carbohydrate Changes}

Desty Ervira Puspaningtyas, Puspita Mardika Sari, Nanda Herdiyanti Kusuma, Debora Helsius SB

Program Studi S-1 IImu Gizi, Fakultas IImu Kesehatan, Universitas Respati Yogyakarta

E-mail: puspaningtyas.desty@gmail.com

\begin{abstract}
Disease treatment and prevention can be done by providing appropriate dietary therapy, such as the use of functional food. Growol, cassava fermented food, is potentially developed as functional food. Cassava fermentation process into growol can change growol's prebiotic potency. Aim of this study was to know growol's prebiotic potency as a functional food based on carbohydrate changes. This was an observational laboratory study. Samples of this study were cassava and growol. Cassava used in this study was Manihot esculenta Crantz. The prebiotics potency was seen from carbohydrate, reducing sugar, sucrose and dietary fiber content. Carbohydrate was analyzed using carbohydrate by difference, while reducing sugar and sucrose were analyzed using Nelson-Somogyi and enzymatic hydrolysis. Gravimetric AOAC enzymatic was used to measure dietary fiber content. Dependent t-test was used to determine the prebiotic potency differences in growol and cassava. Fermentation of cassava into growol statistically reduced total sugar $(p=0.001)$, reducing sugar $(p=0.002)$, and sucrose $(p=0.003)$. Furthermore, fermentation process of cassava into growol increased carbohydrate $(p=0.038)$; insoluble dietary fiber $(p=0.005)$; soluble dietary fiber $(p=0.048)$; and dietary fiber $(p=0.005)$. In conclusion, growol can be potentially developed as functional food in terms of carbohydrate changes, and it expected to be used in disease treatment and prevention. Further studies can examine changes of other nutritional compounds in growol due to fermentation. Moreover, study about health effects of growol administration is needed to be done.
\end{abstract}

Keywords: cassava, fermentation, growol, prebiotic

\section{ABSTRAK}

Pencegahan dan penanganan penyakit dapat dilakukan dengan memberikan terapi diet yang sesuai, salah satunya pangan fungsional. Growol merupakan makanan fermentasi singkong yang potensial dikembangkan sebagai pangan fungsional. Proses fermentasi singkong menjadi growol diduga mampu mengubah potensi prebiotik growol. Tujuan studi ini mempelajari potensi growol sebagai pangan lokal fungsional ditinjau dari potensi kandungan prebiotik. Penelitian ini merupakan penelitian observasional laboratory. Sampel penelitian adalah singkong dan growol. Singkong yang digunakan dalam studi ini adalah Manihot esculenta Crantz. Potensi kandungan prebiotik ditinjau dari perubahan kadar karbohidrat, gula reduksi, sukrosa, dan serat pangan. Analisis karbohidrat dilakukan menggunakan karbohidrat by difference, gula reduksi dan sukrosa dianalisis menggunakan metode Nelson-Somogyi dan metode hidrolisa enzimatik. Kadar serat pangan dianalisis menggunakan metode enzimatik gravimetric AOAC. Dependent $t$-test digunakan untuk mengetahui perbedaan kadar karbohidrat, gula reduksi, sukrosa, dan serat pangan pada growol dan singkong. Proses fermentasi singkong menjadi growol secara statistik mampu menurunkan kadar gula total $(p=0,001)$, gula reduksi $(p=0,002)$, dan sukrosa $(p=0,003)$. Di sisi lain, proses fermentasi singkong menjadi growol dapat meningkatkan kadar karbohidrat $(p=0,038)$; serat pangan tidak larut air $(p=0,005)$; serat pangan larut air $(p=0,048)$; dan serat pangan total $(p=0,005)$. Dapat disimpulkan bahwa growol berpotensi dikembangkan sebagai pangan fungsional ditinjau dari perubahan karbohidrat dan diharapkan growol dapat digunakan dalam penanganan dan pencegahan penyakit. Penelitian selanjutnya dapat mengkaji perubahan senyawa gizi lain yang terjadi akibat fermentasi singkong menjadi growol dan mengkaji efek kesehatan yang dimiliki oleh growol.

Kata kunci: fermentasi, growol, prebiotik, singkong 


\section{PENDAHULUAN}

lom ndonesia merupakan negara berkembang dengan masalah ganda di bidang kesehatan. Indonesia tidak hanya memiliki permasalahan penyakit menular seperti diare dan infeksi saluran nafas, melainkan juga penyakit tidak menular seperti diabetes, penyakit jantung koroner, kanker dan lain sebagainya. Tiga permasalahan kesehatan utama di Indonesia adalah penyakit jantung iskemik, stroke, dan diabetes. ${ }^{1}$ Penyakit tidak menular diperkirakan berkontribusi terhadap 71 persen total kematian di Indonesia dengan kontribusi terbesar berasal dari penyakit kardiovaskular (35\%), kanker (12\%), dan diabetes $(6 \%)^{2,3}$. Penyebab utama terjadinya penyakit tidak menular adalah asupan makan yang kurang baik, tekanan darah yang relatif tinggi, dan kelebihan berat badan. ${ }^{1}$

Pangan fungsional merupakan makanan yang dapat digunakan dalam pencegahan dan penanganan berbagai penyakit dikarenakan kandungan senyawa yang terdapat dalam makanan tersebut. Pangan fungsional memiliki fungsi primer yaitu pangan mampu memenuhi kebutuhan gizi. Selain mampu memenuhi kebutuhan gizi, pangan fungsional juga harus memenuhi kebutuhan sensori makanan. Fungsi lain yang ditawarkan oleh pangan fungsional adalah kemampuan pangan tersebut dalam memberikan manfaat kesehatan dalam hal pencegahan dan penanganan penyakit ${ }^{4-6}$.

Senyawa yang termasuk dalam kategori komponen fungsional adalah probiotik dan prebiotik 5,7,8. Growol, makanan lokal daerah Kulon Progo Yogyakarta, merupakan makanan fungsional hasil fermentasi singkong yang dibuat melalui tahapan perendaman, pencetakan, dan pengukusan. Selama proses perendaman terjadi fermentasi oleh probiotik bakteri asam laktat. Lactobacillus plantarum dan Lactobacillus rhamnosus adalah bakteri utama yang terlibat dalam pembuatan growol. 4,9 Studi sebelumnya telah membuktikan efek konsumsi growol terhadap pencegahan dan penanganan penyakit tidak menular seperti diare terkait peranan growol sebagai sumber probiotik. ${ }^{10}$ Probiotik yang terdapat dalam growol mampu menekan pertumbuhan bakteri penyebab diare.

Proses fermentasi pada makanan tidak hanya berperan sebagai sumber probiotik tetapi juga berpotensi membentuk senyawa prebiotik. Studi sebelumnya menyatakan bahwa proses fermentasi singkong menjadi gathotan dan gathot secara potensial mampu mengubah kadar karbohidrat dan serat pangan. Kadar karbohidrat tertinggi hingga terendah dimiliki oleh singkong, gathotan, dan gathot. Sementara kadar serat pangan tertinggi hingga terendah dimiliki oleh gathot, gathotan, dan singkong. Proses fermentasi singkong menjadi gathotan dan gathot mampu menurunkan kadar karbohidrat dan menaikkan kadar serat pangan. ${ }^{11}$ Proses fermentasi singkong menjadi growol diduga mampu menghidrolisis senyawa karbohidrat (pati, selulosa, dan pektin) menjadi senyawa asam-asam organik. Kandungan karbohidrat seperti gula-gula sederhana yang ada dalam bahan dasar berperan mendukung kehidupan mikrobia alami yang selanjutnya diubah menjadi senyawa asam. ${ }^{12}$

Perubahan potensi prebiotik akibat digunakannya karbohidrat sebagai sumber makanan utama bakteri asam laktat memungkinkan terjadinya penurunan indeks glikemik pada growol. Penurunan indeks glikemik dapat membantu mengontrol kadar glukosa dan lipid darah. Lebih lanjut lagi, serat pangan dan pati resisten juga akan berperan mengontrol kadar profil lipid darah. ${ }^{13,14}$ Dengan kata lain, growol berpotensi untuk digunakan sebagai pangan fungsional dalam penanganan masalah diabetes mellitus dan dislipidemia.

Berdasarkan hasil penelusuran dari studi sebelumnya, pengkajian mengenai potensi growol masih sebatas pada perubahan kadar air, kadar pati, dan kadar protein. Belum terdapat penelitian yang mengkaji perubahan potensi prebiotik akibat proses fermentasi dari singkong menjadi growol.

Penelitian ini bertujuan untuk mengkaji potensi prebiotik growol sebagai pangan lokal fungsional ditinjau dari perubahan karbohidrat pangan. Adanya kajian ini diharapkan dapat menjadi dasar dalam pengembangan growol sebagai alternatif makanan pada penanganan dan pencegahan penyakit. Analisis potensi kandungan prebiotik pada growol menarik untuk dikaji sebagai studi dasar pemanfaaatan pangan fungsional sebagai solusi diet yang efektif dalam terapi penyakit, terutama penyakit yang terkait dengan kelainan metabolisme. ${ }^{15}$ 


\section{METODE PENELITIAN}

Penelitian ini merupakan penelitian observational laboratory yang menganalisis kandungan karbohidrat, gula total, gula reduksi, sukrosa, serat pangan total, serat pangan larut air, dan serat pangan tidak larut air sebagai uji potensi kandungan prebiotik dari singkong dan growol. Studi ini dilakukan di Laboratorium Taksonomi Tumbuhan Fakultas Biologi Universitas Gajdah Mada, Laboratorium Dietetik dan Kuliner Universitas Respati Yogyakarta, Laboratorium Teknologi Pangan Universitas Gadjah Mada, dan Laboratorium Chemix Pratama Yogyakarta pada bulan Mei - Oktober 2018.

Bahan dasar yang digunakan dalam penelitian ini adalah singkong yang dikeringkan dan growol yang dikeringkan. Singkong diperoleh dari petani tradisional di Gunung Kidul, Yogyakarta. Selanjutnya dilakukan uji taksonomi pada singkong di Laboratorium Taksonomi Tumbuhan Fakultas Biologi Universitas Gajdah Mada untuk mengetahui jenis singkong yang digunakan pada penelitian ini.

Growol dalam penelitian ini adalah produk pangan lokal yang dibuat melalui fermentasi alami. Pembuatan growol dilakukan secara modifikasi dengan mengacu pada studi sebelumnya ${ }^{16,17}$ yang diawali dengan sortasi bahan baku, yaitu singkong dikupas, lapisan kulit terluar serta lapisan kulit ari yang mengandung sianida dihilangkan. Selanjutnya, singkong dikupas dipotong-potong dengan ukuran $\pm 5 \mathrm{~cm}$, sehingga diperoleh ukuran bahan yang seragam, selanjutnya dilakukan pencucian hingga 2-3 kali dengan air mengalir. Singkong yang telah bersih direndam dengan menggunakan air sumur bersih dengan perbandingan 1:3 (b/v) selama empat hari. Selanjutnya singkong dicuci dan disaring sebanyak tujuh kali. Setelah pencucian dan penyaringan, singkong diperas dan dikeringkan, selanjutnya disebut sebagai growol mentah. Growol mentah selanjutnya dikukus hingga matang. Pembuatan growol dilakukan di Laboratorium Dietetik \& Kuliner Universitas Respati Yogyakarta. Selanjutnya singkong dan growol dipotong tipis dan dikeringkan dengan kabinet dryer suhu $80^{\circ} \mathrm{C}$ selama dua jam (untuk singkong) dan enam jam (untuk growol).
Singkong dan growol kering kemudian ditepungkan dengan grinder dan diayak dengan ayakan ukuran 80 mesh.

Analisis potensi kandungan prebiotik growol ditinjau dari analisis kadar karbohidrat, gula reduksi, sukrosa, dan serat pangan. Analsis ini memberikan gambaran tidak langsung mengenai potensi prebiotik pada growol mengingat bahwa serat pangan merupakan senyawa yang dapat menginduksi pertumbuhan dan aktivitas mikrobia menguntungkan dalam saluran cerna ${ }^{18}$, sementara perubahan kadar karbohidrat, gula reduksi, dan sukrosa dapat memberikan gambaran penggunaan karbohidrat selama proses fermentasi makanan. ${ }^{12,19}$ Analisis kadar karbohidrat dilakukan secara by difference dengan menghitung $\%$ karbohidrat $=100 \%$ (\%abu+\%air+\%protein+\%lemak). ${ }^{20}$ Analisis gula reduksi dilakukan dengan metode NelsonSomogyi 21, sedangkan analisis sukrosa dilakukan dengan metode hidrolisa enzimatik dan $\mathrm{HCl}^{22}$ Analisis karbohidrat, gula reduksi, dan sukrosa dilakukan di Laboratorium Teknologi Pangan Universitas Gadjah Mada. Analisis serat pangan dilakukan di Laboratorium Chemix Pratama Yogyakarta. Kadar serat pangan dianalisis dengan metode enzimatik gravimetri (AOAC 991.43). ${ }^{23}$

Data dianalisis secara deskriptif dan analitik. Uji statistik dilakukan dengan menggunakan dependent sample t-test (paired t-test) dengan nilai alpha sebesar $95 \%$ untuk membandingkan potensi prebiotik antara singkong dan growol.

\section{HASIL}

Uji taksonomi singkong dilakukan sebelum pengujian kadar karbohidrat, gula reduksi, sukrosa, dan serat pangan. Hal ini dilakukan untuk menjamin bahwa produk growol dibuat dari singkong dengan jenis yang sama. Hasil uji taksonomi singkong menyatakan bahwa species singkong yang digunakan adalah Manihot esculenta Crantz dengan nama lokal singkong atau ubi kayu. Hasil uji taksonomi menyatakan Manihot utilissima Pohl., Janipha manihot (L.) Kunth., Jatropha manihot L., Manihot aipi Pohl., dan Manihot dulcis (J.F.Gmel) Pax merupakan nama lain dari Manihot esculenta Crantz. 
Tabel 1

Perbedaan Potensi Prebiotik dari Proses Fermentasi Singkong Menjadi Growol

\begin{tabular}{lccc}
\hline \multicolumn{1}{c}{ Potensi Prebiotik } & $\begin{array}{c}\text { Singkong } \\
\text { Mean } \pm S D\end{array}$ & $\begin{array}{c}\text { Growol } \\
\text { Mean } \pm S D\end{array}$ & $p$ \\
\hline Karbohidrat & $90,76 \pm 0,26$ & $95,34 \pm 0,12$ & 0,038 \\
Gula Total & $3,14 \pm 0,01$ & $0,23 \pm 0,00$ & 0,001 \\
Gula Reduksi & $1,88 \pm 0,01$ & $0,21 \pm 0,00$ & 0,002 \\
Sukrosa & $1,18 \pm 0,01$ & $0,02 \pm 0,00$ & 0,003 \\
Serat Pangan Total & $10,51 \pm 0,77$ & $13,17 \pm 0,18$ & 0,005 \\
Serat Pangan Tidak Larut Air & $10,08 \pm 0,70$ & $12,59 \pm 0,22$ & 0,005 \\
Serat Pangan Larut Air & $0,43 \pm 0,08$ & $0,58 \pm 0,09$ & 0,048 \\
\hline
\end{tabular}

Growol dapat digunakan sebagai pangan fungsional pada penanganan dan pencegahan penyakit ditinjau dari perubahan potensi kandungan prebiotik pada growol. Hal ini terlihat dari adanya peningkatan jumlah karbohidrat by difference, penurunan kadar gula total, gula reduksi, dan sukrosa, serta peningkatan kadar serat pangan total, serat pangan tidak larut air, dan serat pangan larut air dari fermentasi singkong menjadi growol.

Fermentasi singkong menjadi growol secara signifikan mampu meningkatkan kadar karbohidrat by difference $(p=0,038)$, serat pangan total $(p=0,005)$, serat pangan tidak larut air $(p=0,005)$, dan serat pangan larut air $(p=0,048)$. Selain itu, terjadi penurunan kadar gula total $(p=0,001)$, gula reduksi $(p=0,002)$ dan sukrosa $(p=0,003)$ selama proses fermentasi singkong menjadi growol (Tabel 1).

\section{BAHASAN}

Indonesia merupakan negara yang kaya akan pangan lokal, salah satunya makanan fermentasi dari singkong seperti growol. Growol merupakan makanan tradisional dari Kulonprogo, Yogyakarta yang dibuat dari singkong melalui tahap fermentasi secara spontan dengan cara perendaman dalam air, selanjutnya dicetak, dikukus menjadi growol. $16,24,25$

Proses fermentasi dari singkong menjadi growol terbukti dapat menurunkan kandungan gula total, gula reduksi, dan sukrosa. Perubahan kadar senyawa gula, khususnya gula total, gula reduksi, dan sukrosa dimungkinkan akibat digunakannya senyawa gula sebagai sumber makanan utama bakteri asam laktat. Studi sebelumnya oleh Suharni menyatakan bahwa selama proses perendaman singkong menjadi growol terjadi fermentasi alami oleh berbagai jenis mikrobia, seperti Coryneform, Streptococcus, Bacillus, Actinobacter. Hingga akhir fermentasi, mikrobia lain yang terlibat adalah Lactobacillus dan yeast. ${ }^{4}$ Lebih detail lagi, isolat utama yang terlibat dalam fermentasi singkong menjadi growol adalah genus Lactobacillus dengan spesies Lactobacillus plantarum dan Lactobacillus rhamnosus. Bakteri yang terlibat dalam fermentasi ini bersifat amilolitik yang akan menggunakan karbohidrat sebagai substrat utama mikrobia dalam pembentukan asam laktat.4,9 Bakteri amilolitik ini akan menghidrolisis karbohidrat (pati) sekaligus memfermentasi gula menjadi asam laktat. Proses hidrolisis dan fermentasi inilah yang diduga menjadi penyebab terjadinya penurunan kadar gula total, gula reduksi, dan sukrosa dari fermentasi singkong menjadi growol.

Selain itu, proses pencucian growol juga memungkinkan terjadinya penurunan kadar gula total, gula reduksi, dan sukrosa. Kandungan gula total, gula reduksi, dan sukrosa pada singkong $9-11$ kali lebih tinggi dibandingkan kandungan gula total, gula reduksi, dan sukrosa pada growol. Penelitian sebelumnya menyebutkan bahwa semakin banyak frekuensi penyucian growol, semakin rendah kadar gula reduksi. Kadar gula reduksi pada growol sebelum dicuci adalah $0,0311 \%$ dan menjadi $0,0189 \%$ setelah tiga kali proses pencucian. Beberapa studi menganjurkan agar pencucian growol tidak melebihi tiga kali pencucian. ${ }^{24}$

Ditinjau dari kadar karbohidrat by difference, kadar karbohidrat pada growol lebih tinggi dibandingkan kadar karbohidrat pada 
singkong. Hasil penelitian ini tidak sejalan dengan penelitian sebelumnya pada gathotan dan gathot yang menunjukkan bahwa fermentasi singkong menjadi gathotan dan gathot terbukti dapat menurunkan kandungan karbohidrat. Tidak sejalannya penelitian ini dengan penelitian sebelumnya dimungkinkan karena karbohidrat yang dikaji pada penelitian ini adalah karbohidrat by difference. Karbohidrat yang diukur secara by difference merupakan gambaran karbohidrat setelah dikurangi kadar air, lemak, protein, dan abu. Perhitungan karbohidrat by difference merupakan estimasi jumlah karbohidrat tercerna seperti dekstrin, pati, dan gula; jumlah karbohidrat tidak tercerna seperti pentosan, pektin, hemiselulosa, dan selulosa; serta non-karbohidrat seperti asam organik dan lignin. ${ }^{20,26}$ Penelitian tersebut hanya meninjau perhitungan kasar karbohidrat saja, tanpa melihat pembagian karbohidrat berdasarkan karbohidrat tercerna dan tidak tercerna sehingga tidak dapat diketahui adanya peningkatan karbohidrat ini apakah dikarenakan adanya peningkatan atau penurunan karbohidrat tercerna, karbohidrat tidak tercerna atau non-karbohidrat. Proses fermentasi singkong memberikan pengaruh perubahan kandungan karbohidrat karena bakteri amilolitik akan memecah karbohidrat sekaligus memfermentasi gula menjadi asam laktat selama proses fermentasi. Dalam analisis kadar karbohidrat pada penelitian ini menggunakan kombinasi analsisi kadar gula sederhana, karbohidrat by difference dan analisis kadar serat. Peningkatan kadar karbohidrat pada fermnetasi singkong menjadi growol ini kemungkinan disebabkan karena tingginya kadar karbohidrat tidak tercerna seperti pati resisten, serat pangan yang lebih lama dicerna oleh mikrobia dibandingkan dengan senyawa gula sederhana.

Serat pangan (dietary fiber) adalah jenis karbohidrat yang tidak dapat dicerna oleh enzim a-amilase yang ada dalam tubuh manusia. Perubahan kadar serat pangan terlihat selama proses fermentasi singkong menjadi growol. Proses fermentasi terbukti mampu meningkatkan kadar serat pangan. Penelitian sebelumnya terhadap gathotan dan gathot membuktikan bahwa fermentasi singkong oleh bakteri amilolitik dapat meningkatkan kadar serat pangan total, serat pangan tidak larut air, dan serat pangan larut air. ${ }^{11}$ Sikorsi menyatakan bakteri asam laktat amilolitik pada proses fermentasi alami dapat menghasilkan enzim ekstraseluler yaitu amilase dan pululanase yang dapat menghidrolisis sebagian pati alami menjadi gula reduksi, oligosakarida lain atau dekstrin, dan beberapa pati resisten yang tidak tercerna. ${ }^{27}$ Selanjutnya, beberapa jenis senyawa seperti gula reduksi akan diubah menjadi senyawa asam-asam organik sebagai hasil metabolisme karbohidrat selama proses fermentasi. Hal inilah yang menungkinkan terjadinya penurunan kadar gula reduksi dan peningkatan kadar pati resisten dalam produk fermentasi.

Growol dapat digunakan sebagai solusi diet yang efektif dalam terapi penyakit, baik pada penyakit menular seperti diare ${ }^{10,28}$ dan penyakit kelainan metabolisme ${ }^{15}$ seperti diabetes, dislipidemia, dan penyakit jantung koroner. Hal ini sejalan dengan beberapa kajian yang menyatakan bahwa makanan fermentasi dapat dikembangkan menjadi makanan fungsional dengan fungsi primer, sekunder, dan tersier yang dapat dikembangkan dalam pencegahan penyakit, baik penyakit menular maupun penyakit tidak menular. ${ }^{4-6,29}$ Beberapa penelitian terkait pencegahan dan penanganan penyakit telah dilakukan sebelumnya. Terdapat hubungan signifikan antara konsumsi growol dengan kejadian diare. Semakin sering tingkat konsumsi growol, semakin jarang frekuensi diare. ${ }^{10}$ Selain itu, pemberian growol secara signifikan dapat digunakan pada pencegahan diare yang disebabkan oleh bakteri Enteropathogenic Escherichia coli. Hal ini terlihat bahwa kelompok yang mendapatkan growol memiliki konsistensi feses yang lebih padat dibandingkan kelompok kontrol positif dan negatif. Lebih lanjut lagi, studi ini juga membuktikan bahwa selain memiliki peranan dalam penanganan diare, pada kelompok yang mendapatkan pemberian growol sebanyak 100 persen terjadi penurunan berat badan yang dimungkinkan karena kandungan kalori yang rendah pada growol. ${ }^{30}$ Efek positif ini diduga karena growol merupakan makanan fungsional yang melibatkan fermentasi bakteri probiotik. Adanya peningkatan jumlah serat pangan pada fermentasi singkong menjadi growol mampu memperbaiki massa feses sehingga konsistensi feses menjadi lebih padat. ${ }^{31}$ Selain itu, adanya serat pangan dapat meningkatkan sensasi kenyang lebih lama sehingga penurunan berat 
badan berlangsung lebih optimal. Sebuah ulasan lain menyebutkan bahwa bakteri asam laktat yaitu Lactobacillus TGR-2 yang terdapat pada growol dapat menghambat pertumbuhan bakteri Staphylococcus aureus, Staphylococcus typhimurium, Escherichia coli, Bacillus cereus, dan Moraganella morganii. Sementara Lactobacillus plantarum T-3 yang terdapat pada growol dapat menghambat pertumbuhan bakteri Shigella dysentriae. ${ }^{28}$ Bakteri inilah yang turut mendatangkan manfaat dalam pencegahan dan penanganan diare.

Penurunan kadar gula total, gula reduksi, dan sukrosa akibat proses fermentasi memungkinkan terjadinya penurunan indeks glikemik pada growol. Penurunan indeks glikemik dapat membantu mengontrol kadar glukosa dan lipid darah. Lebih lanjut lagi, serat pangan pada growol juga turut berperan mengontrol kadar glukosa dan profil lipid darah. Semakin tinggi kandungan serat makanan, semakin terkontrol kadar profil lipid dan kadar glukosa darah postprandial. ${ }^{13,14}$ Asupan serat pangan juga berhubungan dengan penurunan plasma lipid, kontrol glikemik, dan penurunan hiperinsulinemia. Peningkatan asupan serat berhubungan dengan perbaikan sekresi dan sensitivitas insulin yang juga berpengaruh dalam metabolisme lemak. ${ }^{14}$ Selain terbukti mampu mengontrol kadar profil lipid, serat pangan dapat menurunkan kadar hemoglobin terglikosilasi (HbA1c). ${ }^{32}$ Serat pangan juga dapat menurunkan absorpsi glukosa dan kolesterol. Akibatnya, serat pangan banyak digunakan dalam terapi pencegahan dan penanganan diabetes dan dislipidemia. Lebih lanjut lagi, serat pangan mampu meningkatkan viskositas digesta sehingga serat pangan dapat digunakan sebagai terapi penderita kanker, khususnya kanker kolon 5,6

Kandungan serat pangan dalam makanan mampu meningkatkan potensi prebiotik. Salah satu peranan prebiotik adalah menstimulasi mikrobia saluran cerna secara selektif yang memproduksi short chain fatty acid (SCFA). Produksi SCFA (asetat, propionat, dan butirat) berperan mencegah kenaikan kolesterol dan kejadian kanker, khususnya kanker kolon serta mengatasi gangguan metabolisme pada obesitas (terkait profil lipid) dan DM tipe 2.5,6,33 Lebih lanjut lagi, serat pangan juga dapat meningkatkan komposisi bakteri asam laktat dalam saluran cerna, yaitu bifidobacteria dan lactobacillus. ${ }^{5}$

Penelitian ini masih memiliki kelemahan, yaitu hanya mengkaji penanda tidak langsung potensi prebiotik pada growol. Kajian lebih lanjut mengenai kandungan karbohidrat tercerna dan karbohidrat tidak tercerna serta jenis asam organik yang terbentuk selama proses fermentasi singkong menjadi growol belum dilakukan dalam penelitian ini, mengingat jenis karbohidrat dan juga asam organik memiliki peranan dalam penanganan dan pencegahan penyakit.

\section{SIMPULAN DAN SARAN}

\section{Simpulan}

Potensi prebiotik pada growol terlihat dari perubahan kadar gula total, gula reduksi, sukrosa, dan serat pangan. Fermentasi singkong menjadi growol terbukti menurunkan kadar gula total, gula reduksi, dan sukrosa. Selain itu, fermentasi singkong menjadi growol terbukti meningkatkan serat pangan total, serat pangat tidak larut air, dan serat pangan larut air. Growol merupakan pangan fungsional yang memiliki potensi prebiotik sehingga growol dapat digunakan dalam penanganan dan pencegahan penyakit, khususnya penyakit tidak menular.

\section{Saran}

Proses fermentasi singkong menjadi growol memungkinkan terjadinya perubahan senyawa gizi lainnya yang turut memiliki peranan dalam penanganan dan pencegahan penyakit. Peneliti selanjutnya dapat mengkaji perubahan senyawa asam-asam organik yang terbentuk selama proses fermentasi, mengingat fermentasi singkong menjadi growol dapat menurunkan kadar gula total, gula reduksi, dan sukrosa. Selain itu, kajian mengenai jenis dan jumlah pati resisten pada growol dapat memperkuat peranan growol sebagai pangan fungsional. Kajian lain yang dapat dilakukan adalah dengan menganalisis perubahan kadar inulin, oligosakarida, dekstrin, pentosan, pektin, hemiselulosa, dan selulosa. Analisis potensi prebiotik growol juga dapat dilakukan baik secara in vitro terhadap pertumbuhan bakteri probiotik dalam media agar maupun secara in vivo sehingga dapat memberikan gambaran 
lebih lanjut mengenai pengaruh growol terhadap keseimbangan mikrobiota saluran cerna.

\section{UCAPAN TERIMA KASIH}

Terima kasih kepada Pusat Penelitian dan Pengabdian Masyarakat Universitas Respati Yogyakarta yang sudah membantu dalam mendanai penelitian ini melalui Hibah Internal Perguruan Tinggi. Nomor kontrak dari penelitian ini adalah 20/PEN/Int/PPPM/IV/2018.

\section{RUJUKAN}

1. Institute for Health Metrics and Evaluation. New study: Indonesia faces a "double burden" of persistent communicable diseases and increasing non-communicable diseases | Institute for Health Metrics and Evaluation [online]. 2018 [cited 2018 Oct 29]. Available from: http://www.healthdata.org/news-

release/new-study-indonesia-faces-"doubleburden"-persistent-communicable-diseasesand

2. World Health Organization. World Health Organization; Non communicable diseases Fact sheet (2018) [online]. 2018 [cited 2018 Oct 29]. Available from: http://www.who.int/news-room/factsheets/detail/noncommunicable-diseases

3. Nugent R. Indonesia Perspectives_Noncommunicable Diseases _ Copenhagen Consensus Center [online]. 2015 [cited 2018 Oct 29]. Available from: https://www.copenhagenconsensus.com/pu blication/indonesia-perspectives-noncommunicable-diseases

4. Nugraheni M. Potensi Makanan Fermentasi Sebagai Makanan Fungsional. Jurusan Pendidikan Teknik Boga dan Busana, Fakultas Teknik, UNY; 2011.

5. Khurniawan A. Pangan Fungsional dan Kesehatan Masyarakat [online]. AKPER Muhammadiyah Cirebon; 2017. 1-10 p. Available from: http://jurnal.akpermuh.ac.id/index.php/jamc/ article/download/42/40

6. Marsono Y. Prospek Pengembangan Makanan Fungsional. J Teknol Pangan dan Gizi [online]. 2008 [cited 2018 Oct 30]; 7(1): 19-27. Available from: http://elearning.unsri.ac.id/pluginfile.php/635 /mod_forum/attachment/23137/ipi113801.pd $\mathrm{f}$

7. Agustina $\mathrm{R}$, Noor RN, Widjayanti RDE, Nuraida L, Ratna N, Nofi LS, et al. Kajian manfaat pangan fungsional setelah terpenuhinya gizi seimbang. PraWidyakarya Nas Pangan dan Gizi [online]. 2018 [cited 2018 Oct 30]. Available from: http://gizi.depkes.go.id/wpcontent/uploads/2018/05/PanganFungsional-Rina-Agustina.pdf

8. Suter IK. Pangan fungsional dan prospek pengembangannya. J lkat Kel Mhs [Online]. 2013 [cited 2018 Oct 29]; 1-17. Available from:

https://repositori.unud.ac.id/protected/storag e/upload/repositori/ID3_1950123119760210 0323091304927makalah-gizi.pdf

9. Putri WDR, Haryadi, Marseno DW, Cahyanto MN. Isolasi dan karakterisasi bakteri asam laktat amilolitik selama fermentasi growol, makanan tradisional indonesia. J Teknol Pertan. 2012; 13(1): 52-60.

10. $R A E$, Lestari $L A$, Juffrie $M$. Frekuensi konsumsi growol berhubungan dengan angka kejadian diare di Puskesmas Galur II Kecamatan Galur Kabupaten Kulonprogo Provinsi DIY. J Gizi Klin Indones (The Indones J Clin Nutr. 2017; 7(1): 27-33.

11. Sari PM, Puspaningtyas DE, Kusuma RJ. Dietary fiber and carbohydrate contents of gathotan and gathot as functional food for people with diabetes mellitus. Indones $\mathrm{J}$ Nutr Diet. 2017; 5(2): 88-92.

12. Nurmalinda A, Periadnadi, Nurmiati. Isolasi dan karakterisasi parsial bakteri indigenous pemfermentasi dari buah durian (Durio zibethinus murr .). Biol Univ Andalas. 2013; 2(1): 8-13.

13. Syamsir E. Pati Resisten Sebagai Sumber Serat Fungsional. Departemen IImu dan Teknologi Pangan, IPB; 2013.

14. Franz MJ. Medical Nutrition Therapy for Diabetes Mellitus and Hypoglycemia of Nondiabetic Origin in Krause's Food \& Nutrition Therapy. 12th ed. Canada: Saunders Elsevier; 2008.

15. Nakamura YK, Omaye ST. Metabolic diseases and pro- and prebiotics: Mechanistic insights. Nutr Metab (Lond) [online]. 2012 [cited 2018 Oct 30]; 9(1): 60. Available from: https://www.ncbi.nlm.nih.gov/pmc/articles/P MC3464869/pdf/1743-7075-9-60.pdf

16. Kanetro B, Luwihana S. Komposisi proksimat dan kandungan bakteri asam laktat oyek terbaik dari perlakuan penambahan kacang tunggak (Vigna unguiculata) berdasarkan tingkat kesukaannya. J Agritech [online]. 2015 [cited 2018 Oct 29]; 35(03): 261. Available 
from:

https://jurnal.ugm.ac.id/agritech/article/view/ 9335

17. Setyowati A, Kanetro B. Kondisi kritis dan umur simpan oyek berprotein tinggi yang dikemas dalam polipropilen dan polietilen. AgriSains. 2015; 6(1): 61-72.

18. Poeker SA, Geirnaert A, Berchtold L, Greppi $A$, Krych L, Steinert RE, et al. Understanding the prebiotic potential of different dietary fibers using an in vitro continuous adult fermentation model (PolyFermS). Sci Rep [online]. 2018 [cited 2019 Sep 21];8(1):4318. Available from: http://www.nature.com/articles/s41598-01822438-y

19. Peters D. Carbohydrates for fermentation. Biotechnol J [online]. 2006 [cited 2019 Sep 21];1(7-8):806-14. Available from: http://www.ncbi.nlm.nih.gov/pubmed/16937 414

20. Yenrina IR. Metode Analisis Bahan Pangan dan Komponen Bioaktif. 2015. 1-167 p.

21. Al-kayyis $\mathrm{H}$, Susanti $H$. Perbandingan metode Somogyi-Nelson dan anthronesulfat pada penetapan kadar gula pereduksi dalam umbi Cilembu (Ipomea batatas L.). J Farm Sains dan Komunitas. 2016; 13(2): 81-9.

22. Pontoh J. Penentuan kandungan sukrosa pada gula aren dengan metode enzimatik. Chem Prog. 2013; 6(1): 26-33.

23. Centre for Food Safety. Analysis of Dietary Fibre [online]. Food and Environmental Hygiene Department; 2009 [cited 2018 Oct 29]. Available from: https://www.cfs.gov.hk/english/programme/p rogramme_nifl/files/Total_dietary_fibre.pdf

24. Wariyah $\bar{C}$, Luwihana $\bar{S}$. The effects of washing on the chemical properties and bacteria content of fermented cassava (a case study in the growol rural industry, Kalirejo Village, Kokap, Kulon Progo, DIY) in Proceeding International Food Conference 2016 Innovation of Food Technolo. Epriliati I, Kuswardani I, Ingani A, Marsono Y, Sutriswati E, Otunola ET, et al., editors. 2016

25. Lestari LA. Potensi probiotik lokal sebagai makanan fungsional pencegah diare [online]. 2009 [cited 2018 Oct 29]. Available from:

http://gizikesehatan.ugm.ac.id/2009/06/pote nsi-probiotik-lokal-sebagai-makanan-

fungsional-pencegah-diare/

26. A Dictionary of Food and Nutrition. carbohydrate by difference |
Encyclopedia.com
[online]. Oxford University Press. 2005 [cited 2019 Sep 21]. Available from: https://www.encyclopedia.com/education/dic tionaries-thesauruses-pictures-and-pressreleases/carbohydrate-difference

27. Astriani. Karakterisasi gatot terfermentasi oleh isolat indigenus gatot singkong (Rhizopus oligosporus dan Lactobacillus manihotivorans) (skripsi) [online]. Jurusan Teknologi Hasil Pertanian Fakultas Teknologi Pertanian Universitas Jember; 2015 [cited 2018 Oct 29]. Available from: http://repository.unej.ac.id/bitstream/handle/ 123456789/67107/101710101009

Astriani.pdf?sequence $=1$

28. Nuraida L. A review: Health promoting lactic acid bacteria in traditional Indonesian fermented foods. Food Sci Hum Wellness [online]. 2015 [cited 2018 Oct 30]; 4(2): 4755. Available from: http://linkinghub.elsevier.com/retrieve/pii/S2 213453015000294

29. Suhartatik N, Cahyanto $M$, Rahardjo $S$, Miyashita M, Rahayu E. Isolation and identification of lactic acid bacteria producing $\beta$ glucosidase from Indonesian fermented foods. Int Food Res J. 2014; 21(3): 973-8.

30. Prasetia KD, Kesetyaningsih TW. Effectiveness of growol to prevent diarrhea infected by enteropathogenic escherichia coli. Int J ChemTech Res. 2015; 7(6): 260111.

31. Slavin J. Fiber and Prebiotics: Mechanisms and Health Benefits. Nutrients [online]. 2013 [cited 2019 Sep 21];(5):1417-35. Available from:

https://www.ncbi.nlm.nih.gov/pmc/articles/P MC3705355/pdf/nutrients-05-01417.pdf

32. Post RE, Mainous AG 3rd, King DE, Simpson KN. Dietary fiber for the treatment of type 2 diabetes mellitus: a meta-analysis. J Am Board Fam Med. 2012; 25(1): 16-23.

33. Everard A, Cani PD. Diabetes, obesity and gut microbiota. Best Pract Res Clin Gastroenterol [online]. 2013 [cited 2018 Oct 30]; 27(1): 73-83. Available from: http://dx.doi.org/10.1016/j.bpg.2013.03.007 